\title{
Reduction of Cycle Time in Vehicle Engine Assembly Line Using Karakuri Kaizen
}

\author{
Alur Pogowonto ${ }^{1}$, Uly Amrina ${ }^{2}$ \\ ${ }^{1-2}$ Industrial Engineering Department \\ Faculty of Engineering, Universitas Mercu Buana \\ J1. Raya Meruya Selatan, Kembangan, Jakarta 11650 \\ Indonesia
}

\begin{abstract}
Just In Time (JIT) based automotive manufacturing companies use the takt time and cycle time as indicators of their manufacturing performance. This study explores the vehicle engine assembly line for Station 2 Cylinder Block Products, which has a cycle time of 184 seconds, while the company targets a 180 second for takt time. Though ideally, the cycle time should not exceed the takt time. This research aims to identify the Non-Value Added (NVA) activities in Station 2 and minimize them with Karakuri Kaizen. The results of the Process Activity Mapping (PAM) show that Station 2 Cylinder Block has 16 Value Added (VA) activities, 19 Necessary Non-Value Added (NNVA) activities, and 7 Non-Value Added (NVA) activities with a manufacturing cycle effectiveness (MCE) 78\%. Based on the activity mapping, the researchers find the primary causes and designed a proposed improvement using the Karakuri Kaizen method to reduce two NVA activities. The company can speed up the cycle time at Station 2 Cylinder Block to 180 seconds and the MCE to $80 \%$ by implementing Karakuri Kaizen.
\end{abstract}

Key Words: Cycle Time, Non-Value Added Activity, Process Activity, Mapping, Karakuri Kaizen, Vehicle Engine.

\section{INTRODUCTION}

The four-wheeled vehicle manufacturing industry develops from time to time because of the increasing demand every year. Gaikindo stated that the number of four-wheeled vehicle production in Indonesia has increased by 244,923 units from 2015 to 2019 [1]. The increase in the number of car production drives the vehicle engine industry's growth and requires every vehicle engine Manufacturing company to compete and always improve productivity performance while controlling production costs. It also encourages several automotive manufacturing companies to use the Toyota Production System (TPS) as their production system. TPS is a method that helps product manufacturers to achieve better profits [2]. TPS aims to provide products with the best quality, lowest cost, and shortest production lead time by eliminating waste during production. TPS consists of two main pillars, namely Just In Time (JIT) and Jidoka supported by Kaizen, Work Standardization, Heijunka, PDCA, 5S, Total Productive Maintenance (TPM), and other manufacturing strategies as the foundation [3]. Companies that use JIT have two main times, namely the tact time and the cycle time, to calculate and measure the timeframe of various processes and the average time per item. According to Imai, takt time is the available production time divided by the number of units demanded by consumers [4]. Takt time is a theoretical value that refers to how long it takes to complete one product unit in each process. Meanwhile, cycle time is the real-time needed for operators to complete their operational tasks. The basic idea in JIT is to make the cycle time as close to the takt time as possible but not to exceed the takt time.

As the research subject, the vehicle engine company has two parts in the production division, namely machining and assembly line. The assembly line has a takt time of 3.0 minutes or 180 seconds with 17 stations. The assembly line consists of the Sub Line, which works on the engine's core parts with 11 stations, and the Main Line, which works on the exterior or accessories for car engines with six stations. 


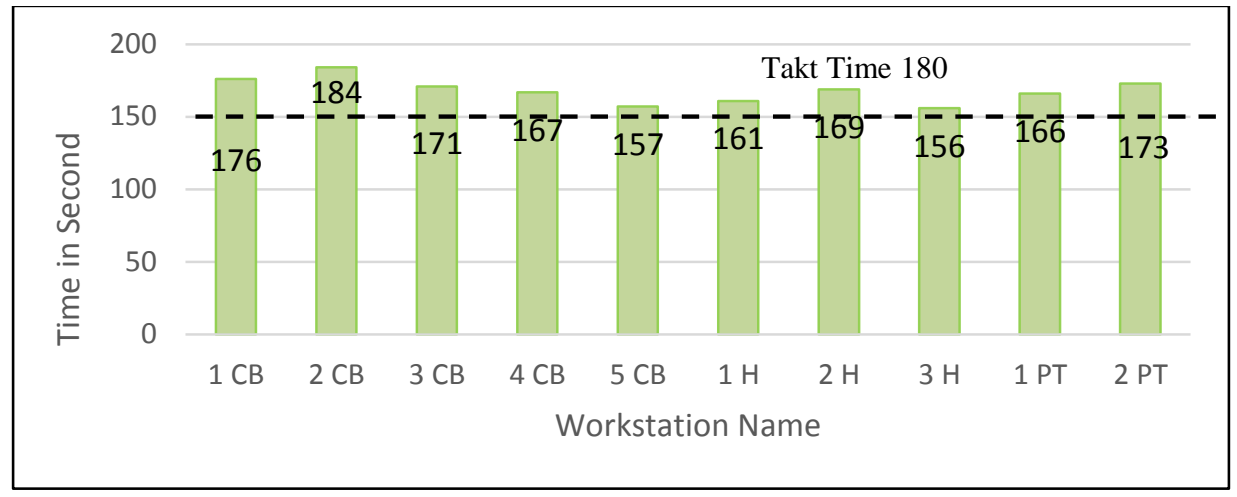

Figure 1. Yamazumi Chart Sub Line - Engine Assembling

Figure 1 shows a graph of the Yamazumi sub line with a total cycle time of 1958 seconds, divided into 11 stations. It visualizes that Station 2 Cylinder Block has a cycle time of 184 seconds, which exceeds the target Takt Time of 180 seconds. That condition will hamper production's timeliness because, ideally, the cycle time should be lower than the Takt time. This research will map the details of the work elements at Station 2, find the primary causes, and design suggestions for improvements that can reduce cycle time at Station 2 Cylinder Block and increase the Sub Line's manufacturing effectiveness.

\section{LITERATURE SURVEY}

Lean Manufacturing defines as a systemic and systematic approach to identify and eliminate losses through continuous improvement [5], [6]. It implements pull systems by flowing products (materials, work in process, output), and information from internal and external customers to pursue excellence in the manufacturing industry [7]. Lean Manufacturing is a combination of several tools to help eliminate non-value-added activities to products, services, or processes. It aims to improve processes by eliminating the losses [8]. Lean Manufacturing is a goal that many companies want to achieve since it provides long-term benefits.

\subsection{Process Activity Mapping}

The purpose of PAM is to identify the lead time and productivity of physical product and information flows [9]. Process activity mapping's basic concept is to map every activity stage from operations, inspection, transportation, delay, and storage [10]. Furthermore, they grouped into existing types of activity types, namely Value-Adding Activities (VA), Necessary Non-ValueAdding Activities (NNVA), and Non-Value Adding Activities (NVA). PMA helps to understand the flow of the process, identify waste, and what kind of strategies to improve manufacturing effectiveness.

\subsection{Manufacturing Cycle Effectiveness (MCE)}

Manufacturing Cycle Effectiveness (MCE) is a measure to show the percentage of value-added activities contained in activities when companies use them to generate value for customers [11]. The formula for calculating the manufacturing cycle effectiveness visualize in Equation 1 [12].

$$
\text { MCE }=\frac{\text { Process Time }}{\text { Processing Time }+ \text { Inspection Time }+ \text { Waiting Time }+ \text { Move Time }}
$$

If the manufacturing process produces a manufacturing cycle effectiveness of $1(100 \%)$, it means the process does not have NVA. The manufacturer does not burden the costs of non-value-added activities to the customer [13]. Conversely, if the manufacturing cycle effectiveness is less than 1 , it means that the process still contains activities not required by the customer.

\subsection{Fishbone Diagram}

A fishbone diagram is an approach that allows more detailed analysis in suggesting the causes of a problem, discrepancies, and gaps [14]. The Fishbone diagram has advantages which include visual clarity of the diagram and helps to explore ideas from the thoughts of several people in detail by basing it on a set of categories [15], namely:

1) Man (people), namely all the people involved in a process.

2) Method (method), namely how the process is carried out, such as procedures, rules, and others.

3) Material (materials), namely all the materials needed to carry out the process.

4) Machine (machine), namely all machines, equipment, computers, and others needed to work.

After finding the cause of the problem, the decision-maker can determine a repair strategy using the kaizen approach. 


\subsection{Karakuri Kaizen}

Kaizen is a continuous improvement that is carried out by eliminating waste, eliminating excess workload, and always improving product quality [16], [17]. The main goal of kaizen is to eliminate waste that does not add value to the product or service [18], [19]. Kaizen has several concepts that companies can use in making improvements, some of these concepts, namely the $3 \mathrm{M}$ concept, the 5S movement concept, the PDCA concept, the 5W + 1H concept, Karakuri kaizen, and others [20].

Karakuri is a mechanical device used in factories that minimizes electricity usage [21]. At the same time, Karakuri Kaizen improved material handling by relying on gravity, lever and cam utility, and utilizing inertia to move and transfer goods [22]. This concept helps move material from machine to machine, from machine to operator, or from operator to machine. Karakuri Kaizen in the manufacturing industry has the following advantages [23]:

1) In terms of investment in existing goods, Karakuri has a cheaper investment than an investment in used electronic goods.

2) Easy and inexpensive maintenance because the use of materials is not too much, and there is no need to call technicians or programming in case of damage.

3) Karakuri is easy and fast in the development process compared to electricity-based equipment.

The steps in applying Karakuri Kaizen are as follows [24]:

1) Planning Strategy. The application of the Karakuri concept considers the smoothness of the production line process flow. The Karakuri concept does not interfere with the flow of processes and operators during the production process. Karakuri aimed to reduce waste of operators' motion with the conditions of the production line itself. Besides, the Karakuri system is smaller in dimensions and is suitable for placing in the production process line. We have to make a planning strategy to design the Karakuri, such as making layout drawings.

2) Design Selection. The next step is to choose a design based on space and suitability since space limitations will disrupt the process and cycle times. The Karakuri concept was designed with cost and space in mind. The cost to produce a Karakuri design should be less wasteful, cheap, and affordable. Besides, the Karakuri design must be simple so that the implementation method is not complicated.

3) Karakuri's analysis shows actual results in terms of waste reduction, employee ergonomics, employee safety, employee efficiency, and company profits.

\section{RESEARCH METHOD}

This quantitative type of research collects primary data and secondary data. Primary data comes from observation and measurement data, while secondary data is in the form of Combined Work Standards obtained from companies, assembly line departments. After obtaining all the required data, the researchers process the data following the steps in Figure 2.

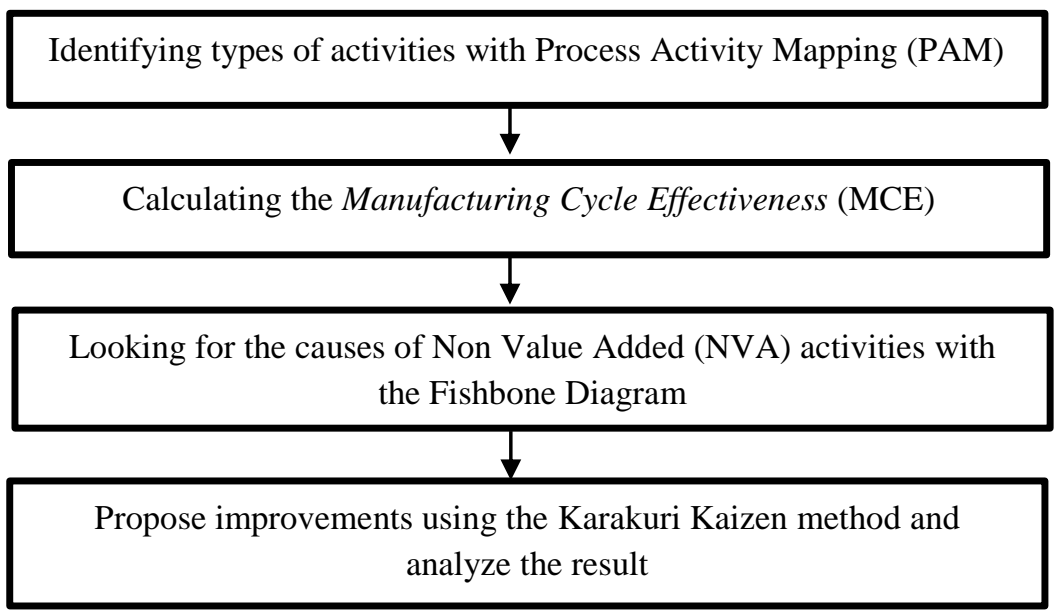

Figure 2. Research Steps 


\section{RESULT AND DISCUSSION}

\subsection{Result of Process Activity Mapping (PAM)}

Station 2 - Cylinder Block has 42 activities with a total cycle time of 184 seconds, as mapped in Table 1.

Table 1 Process Activity Mapping (PAM)

\begin{tabular}{|c|c|c|c|c|c|c|}
\hline \multirow{2}{*}{ No } & \multirow{2}{*}{ Work Element } & \multirow{2}{*}{$\begin{array}{c}\text { Time } \\
\text { (Seconds) }\end{array}$} & \multicolumn{3}{|c|}{ Activity Type } & \multirow{2}{*}{ Working Type } \\
\hline & & & VA & NNVA & NVA & \\
\hline 1 & Take the CB Slipper and put it on the CB & 3 & & $\checkmark$ & & Process Time \\
\hline 2 & Put CB into tilting & 2 & & $\checkmark$ & & Process Time \\
\hline 3 & Turn the titling $180^{\circ}$ with the lower face up & 2 & & $\checkmark$ & & Process Time \\
\hline 4 & Remove the CB from the titling & 2 & & $\checkmark$ & & Process Time \\
\hline 5 & Return the titling to its original position & 2 & & & $\checkmark$ & Moving Time \\
\hline 6 & Take the barcode from the hanger & 2 & & $\checkmark$ & & Process Time \\
\hline 7 & Put on the oil filter cover & 3 & $\checkmark$ & & & Process Time \\
\hline 8 & $\begin{array}{l}\text { Match the engine number on the glass with the } \\
\text { barcode number + marking }\end{array}$ & 3 & & $\checkmark$ & & Inspection Time \\
\hline 9 & Push the CB into the nozzle jet mount & 2 & & & $\checkmark$ & Moving Time \\
\hline 10 & Look at and press the variant ID & 4 & & $\checkmark$ & & Process Time \\
\hline 11 & Install the nozzle jet (4/4) & 28 & $\checkmark$ & & & Process Time \\
\hline 12 & Torque bolt nozzle jet (4/4) & 8 & $\checkmark$ & & & Process Time \\
\hline 13 & Check confirmation of nozzle jet + marking & 3 & & $\checkmark$ & & Inspection Time \\
\hline 14 & $\begin{array}{l}\text { Take the engine variant kanban and put it on the } \\
\text { plastic }\end{array}$ & 2 & & $\checkmark$ & & Process Time \\
\hline 15 & $\begin{array}{l}\text { Put the variant kanban and barcode between the CB } \\
\text { and the slipper }\end{array}$ & 3 & & $\checkmark$ & & Process Time \\
\hline 16 & Push CB to open the bolt crank cap & 2 & & & $\checkmark$ & Moving Time \\
\hline 17 & Open the bolt crank cap with impact & 19 & $\checkmark$ & & & Process Time \\
\hline 18 & Check (turn) the bolt crank cap with both hands & 4 & & $\checkmark$ & & Inspection Time \\
\hline 19 & Lift the crank cap with SST & 7 & $\checkmark$ & & & Process Time \\
\hline 20 & Pull the $\mathrm{CB}$ to the lower bearing installation & 3 & & & $\checkmark$ & Moving Time \\
\hline 21 & Enter the bearing size data of the crankshaft & 6 & $\checkmark$ & & & Process Time \\
\hline 22 & Clean the gloves with a tissue & 2 & & $\checkmark$ & & Process time \\
\hline 23 & $\begin{array}{l}\text { Check the crankshaft lower bearing size on the } \\
\text { monitor screen }\end{array}$ & 2 & & $\checkmark$ & & Inspection Time \\
\hline 24 & $\begin{array}{l}\text { Select the lower crankshaft (RR-FR) bearing and } \\
\text { attach it to the jig }\end{array}$ & 6 & $\checkmark$ & & & Process Time \\
\hline 25 & $\begin{array}{l}\text { Clean the lower bearing surface with a white cloth } \\
\text { and press the button }\end{array}$ & 4 & $\checkmark$ & & & Process Time \\
\hline 26 & Open Cap and clean the surface of the bearing & 8 & $\checkmark$ & & & Process Time \\
\hline 27 & $\begin{array}{l}\text { Mount on the jig and push the lower jig bearing into } \\
\text { the crankshaft mounting }\end{array}$ & 4 & & & $\checkmark$ & Moving Time \\
\hline 28 & Clean the upper bearing surface on the $\mathrm{CB}$ & 3 & $\checkmark$ & & & Process Time \\
\hline 29 & Install the upper jig bearing on the $\mathrm{CB}$ & 2 & $\checkmark$ & & & Process Time \\
\hline 30 & Clean the gloves with a tissue & 2 & & $\checkmark$ & & Process time \\
\hline 31 & $\begin{array}{l}\text { Check the crankshaft upper bearing size on the } \\
\text { monitor screen }\end{array}$ & 2 & & $\checkmark$ & & Inspection Time \\
\hline 32 & $\begin{array}{l}\text { Select the bearing Crankshaft upper and wipe the } \\
\text { striped bearing with a wedge }\end{array}$ & 6 & $\checkmark$ & & & Process Time \\
\hline 33 & Install the upper crank bearing on the jig (FR-RR) & 3 & $\checkmark$ & & & Process Time \\
\hline 34 & Visual check bearing crankshaft upper + marking & 2 & & $\checkmark$ & & Inspection Time \\
\hline 35 & $\begin{array}{l}\text { Press the bearing and remove the upper bearing jig } \\
\text { from the } \mathrm{CB}\end{array}$ & 2 & $\checkmark$ & & & Process Time \\
\hline
\end{tabular}


International Journal of Engineering Research And Advanced Technology, Vol.6 (10), October-2020

\begin{tabular}{|c|c|c|c|c|c|c|}
\hline 36 & $\begin{array}{l}\text { Check grove bearing and oil hole crankshaft with } \\
\text { SST cleaning bearing upper }\end{array}$ & 3 & & $\checkmark$ & & Inspection Time \\
\hline 37 & Slide the CB into the crankshaft mounting & 2 & & & $\checkmark$ & Moving Time \\
\hline 38 & Apply Oil to the upper crankshaft bearing & 4 & $\checkmark$ & & & Process Time \\
\hline 39 & Check the visual crankshaft & 4 & & $\checkmark$ & & Inspection Time \\
\hline 40 & $\begin{array}{l}\text { Take the hoist and attach the crankshaft to the CB } \\
\text { and Return the hoist }\end{array}$ & 5 & & $\checkmark$ & & Process Time \\
\hline 41 & $\begin{array}{l}\text { Put the lower bearing on the } \mathrm{CB} \text { and enter the } \\
\text { bearing size data of the crankshaft }\end{array}$ & 6 & $\checkmark$ & & & Process Time \\
\hline 42 & Push the jig back into position & 2 & & & $\checkmark$ & Moving Time \\
\hline & Total Cycle Time & \multicolumn{5}{|c|}{184} \\
\hline & Number of VA & \multicolumn{5}{|c|}{16 (115 seconds) } \\
\hline & Number of NNVA & \multicolumn{5}{|c|}{19 (52 seconds) } \\
\hline & Number of NVA & \multicolumn{5}{|c|}{7 (17 seconds) } \\
\hline & Total Process Time & \multicolumn{5}{|c|}{144 seconds } \\
\hline & Total Inspection Time & \multicolumn{5}{|c|}{23 seconds } \\
\hline & Total Moving Time & \multicolumn{5}{|c|}{17 seconds } \\
\hline
\end{tabular}

The activities in Table 1 can be grouped into:

1) 16 VA activities, with a total time of 115 seconds.

2) NNVA as many as 19 jobs, with a total time of 52 seconds.

3) NVA activities as many as seven jobs, with a total time of 17 seconds.

NVA at Station 2 - Cylinder Block, occurs at the time of moving goods. For this reason, the researcher focuses on making suggestions for improvements to the activity of moving goods aimed at reducing NVA.

\subsection{Manufacturing Cycle Effectiveness (MCE) Calculation}

The next step is to carry out the calculation process to determine cost-effectiveness using the Manufacturing Cycle Effectiveness (MCE) tool. Based on PMA, the total process time is 144 seconds, the total inspection time is 23 seconds, and the total waiting time is 17 seconds. So that the calculation of the MCE value is as follows.

$$
\mathrm{MCE}=\frac{144}{144+23+17}=\frac{144}{184}=0,78
$$

Based on the above calculations, the MCE value at Station 2 Cylinder Block is $78 \%$. By making improvement proposals, the researchers expect to increase the MCE value at Station 2 Cylinder Block.

\subsection{Fishbone Diagram}

Based on the PAM table, there are 7 NVA activities at Station 2 Cylinder Block, which only occur in moving time activities with 17 seconds. Then the researchers brainstormed with the section head and line head to determine the cause of the NVA using a fishbone diagram. 


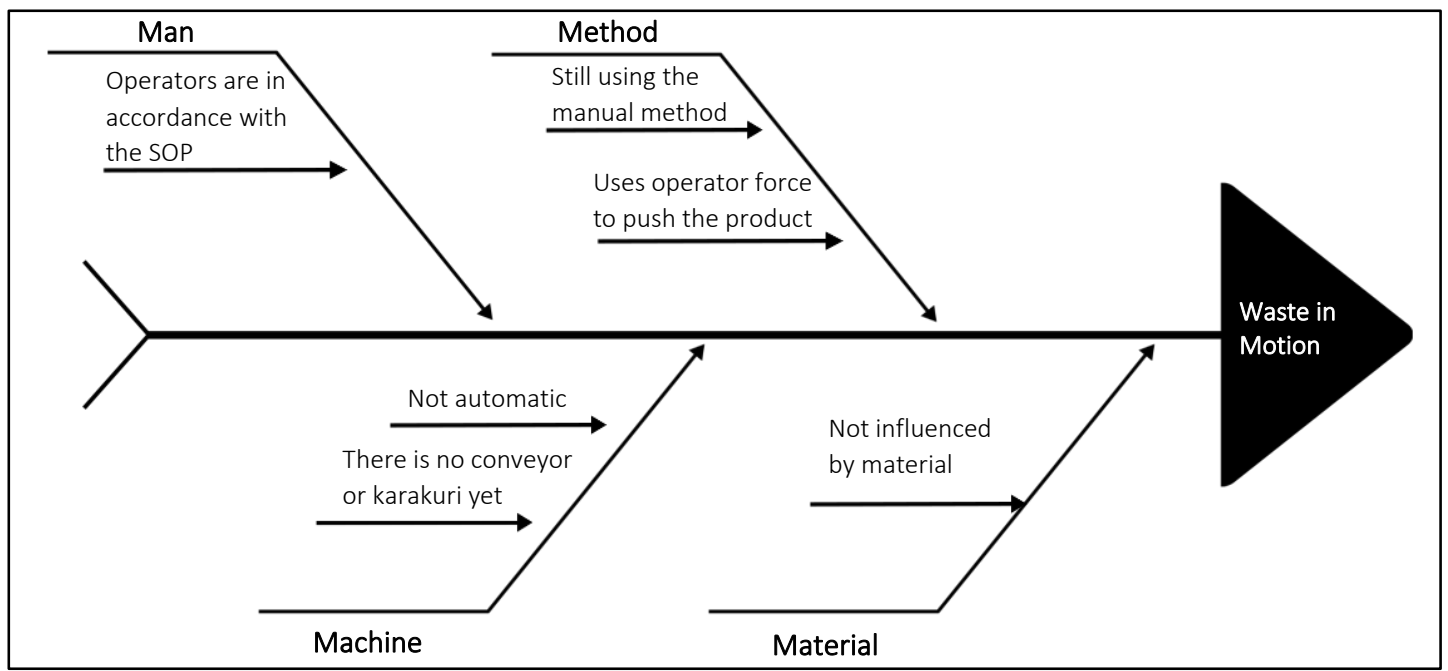

Gambar 3. Fishbone Diagram

The results of the fishbone diagram concluded that the causes of NVA at Station 2 Cylinder Block is the method of moving the product is still manual by using the operator's power to move the cylinder block and jig. The researchers designed improvements by applying Karakuri, which can reduce NVA in the process of moving goods.

\subsection{Proposed Improvement Using Karakuri Kaizen}

Based on the job element at PMA, there is an activity to push the jig that occurs repeatedly. The activity of pushing the jig is in the bearing installation area and the crankshaft installation area. This activity can be improved using the Karakuri Kaizen with a seesaw mechanism. The working principle of Karakuri Kaizen here is to take advantage of the weight of the cylinder block. This research proposes changes to the lower shutter jig bearing, which is initially static, to move up and down like tipping and add a cylinder block holder to the crankshaft installation to trigger the shutter drop by taking advantage of the weight of the cylinder block. The steps in designing the proposal are as follows:

1) It was adding support in the middle of the lower shutter jig bearing, thus changing the lower shutter jig bearing o be able to move up and down.

2) Create a trigger on the lower shutter jig bearing so that it can throw by making a flat cylinder block holder connected to the lower shutter jig bearing in the crankshaft mounting area $1 \mathrm{~cm}$ higher than the roller. Thus, if the cylinder block is in the crankshaft installation area, the lower shutter jig bearing will tilt to the left.

3) Add a weight to the lower shutter jig bearing's right so that the lower shutter jig bearing can tilt to the right. The minimum weight of the cylinder block is $50.2 \mathrm{~kg}$, and the weight of the lower jig bearing is $3 \mathrm{~kg}$, so a weight of 10 $\mathrm{kg}$ is needed.

4) Create a stopper to the lower shutter jig bearing and below the trigger to prevent the lower shutter jig bearing's excessive tilting.

Figure 4 illustrates a workplace at Station 2 - Cylinder Block before repair and after repair using Karakuri Kaizen.
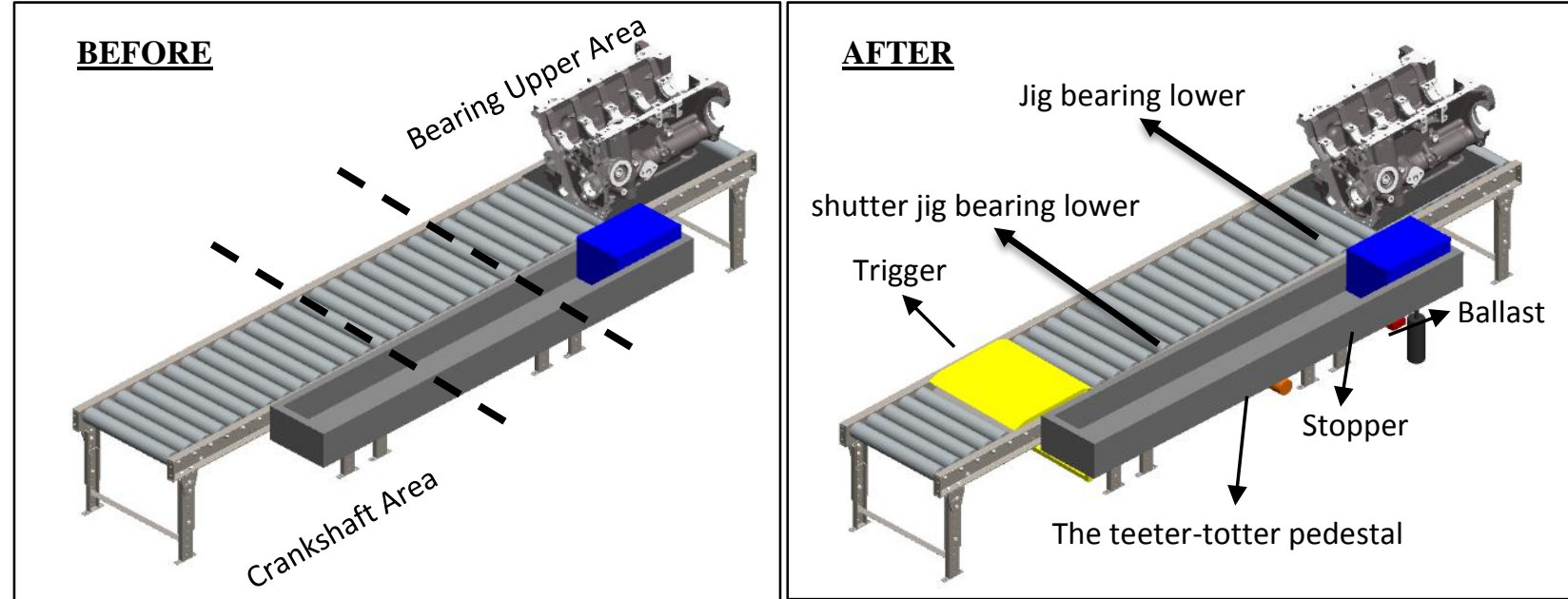

Figure 4. Illustration of Station 2 - Cylinder Block before repair (left) and after repair (right) 
The proposed Karakuri Kaizen design mechanism is as follows

1) Initial Position

The initial position is the position of the cylinder block in the upper bearing installation area. This step occurs after the cylinder block enters Station 2, as shown in Figure 5. With the cylinder block positioned in the upper bearing installation area, the trigger will not load. It will make the lower shutter jig bearing get $10 \mathrm{~kg}$, making the jig bearing tilt to the right. The stopper makes the jig tilt-only 1 degree.

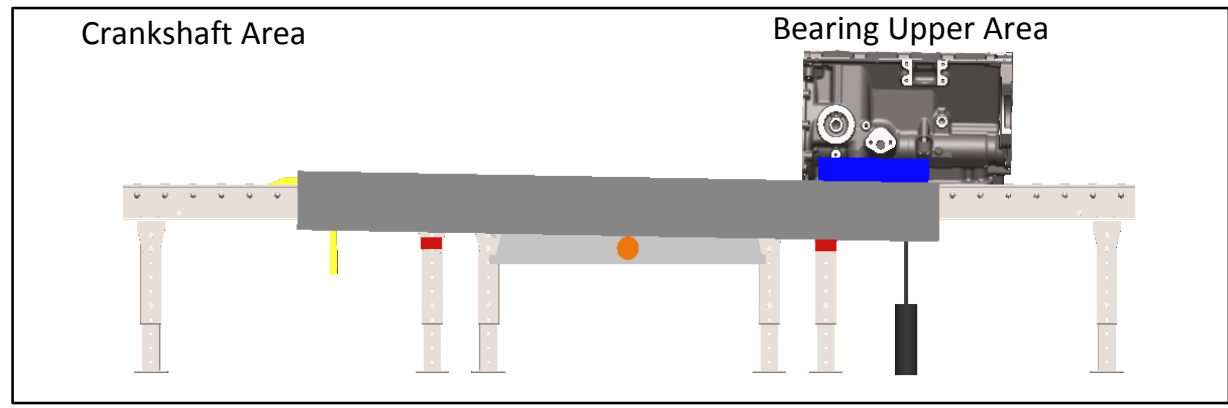

Figure 5. Initial Position When the Product Enters Station 2

2) Ending Position

The final position is the position of the cylinder block in the crankshaft installation area. This stage occurs after the operator pushes the cylinder block from the upper bearing installation area to the crankshaft installation area, as shown in Figure 6.

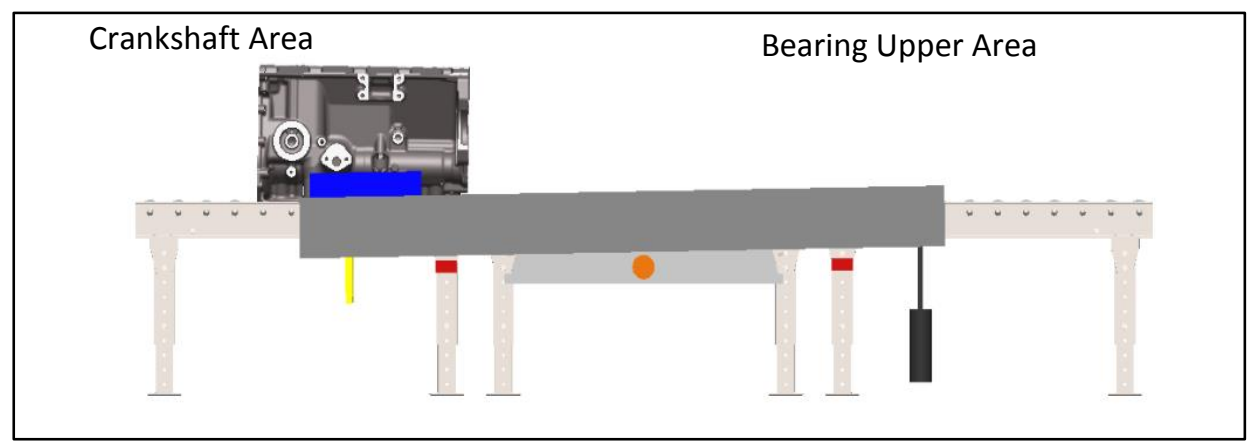

Figure 6. The Final Position When the Product Leaves the Station 2

The trigger will get a load of $50 \mathrm{~kg}$ from the cylinder block and drop to the roller. The lower shutter jig bearing will get the same load as the trigger that makes the jig tilt to the left. The stopper makes a tilt of only 2 degrees. Then, the lower jig bearing will move to the left.

The proposed design is estimated to eliminate two work elements and reduce the time by 4 seconds. Table 2 shows an estimated comparison of Station 2 performance before and after the improvement.

Table 2. Comparison Before and After Improvement at Station 2

\begin{tabular}{|l|c|c|}
\hline \multicolumn{1}{|c|}{ Parameter } & $\begin{array}{c}\text { Before } \\
\text { Improvement }\end{array}$ & After Improvement \\
\hline Total Cycle Time & 184 seconds & 180 seconds \\
\hline Total Moving Time & 17 seconds & 13 seconds \\
\hline Total Non Value Added & 7 activities & 5 activities \\
MCE & $78 \%$ & $80 \%$ \\
\hline
\end{tabular}

Table 1 shows four changes that occurred if the company implements Karakuri Kaizen. These changes include the total cycle time, moving time, the number of Non-value added activities, and the MCE value. These four parameters can be a strong motivation for the company to execute the proposed Karakuri Kaizen design. 


\section{CONCLUSION}

Process Activity Mapping (PAM) at Station 2 - Cylinder Block classifies 16 Value Added (VA) activities, 19 Necessary NonValue Added (NNVA) activities, and 7 Non-Value Added (NVA) activities. Researchers measured VA activity time was 144 seconds, NNVA was 19 seconds, and NVA was 17 seconds. By calculating Manufacturing Cycle Effectiveness (MCE), the 2 Cylinder Block Workstation has an MCE value of 78\%. To minimize NVA, researchers designed improvements using the Karakuri Kaizen technique to push the lower bearing jig so that a lower shutter jig bearing can move up and down like a seesaw by utilizing the weight of the cylinder block and the ballast. If the company management implements the design, he can increase the MCE value by $2 \%$ to $80 \%$.

\section{ACKNOWLEDGMENT}

We are grateful to the Universitas Mercu Buana, who funded this research. We also would like to thank the vehicle engine factory's management for allowing us to explore the Cylinder Block Assembly Workstation during the research period without publishing the company name.

\section{REFERENCES}

1. Gaikindo. (2020). Gaikindo Production Data 2019. Available from: https://www.gaikindo.or.id/indonesianautomobile-industry-data.

2. Monden, Y. (2011). Toyota Production System: An Integrated Approach to Just-in-Time. CRC Press.

3. Loyd, N., G. Harris, S. Gholston, \& D. Berkowitz. (2020). Development of a Lean Assessment Tool and Measuring the Effect of Culture from Employee Perception. Journal of Manufacturing Technology Management. https://doi.org/10.1108/JMTM-10-2019-0375

4. Imai, M. (1997). Gemba Kaizen: A Commonsense, Low-Cost Approach to Management. New York: McGrawHill. XXX.

5. Amrina, U. and T.Y.M. Zagloel. (2019). The Harmonious Strategy of Lean and Green Production: Future Opportunities to Achieve Sustainable Productivity and Quality. Paper presented at the 2019 IEEE 6th International Conference on Industrial Engineering and Applications (ICIEA).

6. García-Alcaraz, J.L., A.A. Maldonado-Macías, \& G. Cortes-Robles. (2014). Lean Manufacturing in the Developing World. Springer.

7. Ramadan, M., B. Salah, M. Othman, \& A.A. Ayubali. (2020). Industry 4.0-Based Real-Time Scheduling and Dispatching in Lean Manufacturing Systems. Sustainability, 12(6), 2272. https://doi.org/10.3390/su12062272

8. Ikatrinasari, Z.F., S. Hasibuan, \& K. Kosasih. (2018). The Implementation Lean and Green Manufacturing through Sustainable Value Stream Mapping. Paper presented at the IOP Conference Series: Materials Science and Engineering.

9. Amrina, U. and M.U.R. Fitrahaj. (2020). An Application of Value Stream Mapping to Reduce Waste in Livestock Vitamin Raw Material Warehouse. International Journal of Science and Research 9(3).

10. Hines, P., M. Holweg, \& N. Rich. (2004). Learning to Evolve: A Review of Contemporary Lean Thinking. International Journal of Operations \& Production Management, 24(10), 994-1011. https://doi.org/10.1108/01443570410558049

11. Putri, NT and L.S. Dona. (2019). Application of Lean Manufacturing Concept for Redesigning Facilities Layout in Indonesian Home-Food Industry. The TQM Journal. https://doi.org/10.1108/TQM-02-2019-0033

12. Parmenter, D. (2015). Appendix E: Performance Measures Database, in Key Performance Indicators: Developing, Implementing, and Using Winning KPIs, Third Edition. John Wiley \& Sons, Inc: Hoboken, NJ, USA. p. 349-397.

13. Hariastuti, N. and D. Saputra. (2019). Implementation of Waste Reduction at Operational Division with Lean Manufacturing Concept. Paper presented at the IOP Conference Series: Materials Science and Engineering.

14. Nandakumar, N., P. Saleeshya, \& P. Harikumar. (2020). Bottleneck Identification and Process Improvement by Lean Six Sigma Dmaic Methodology. Materials Today: Proceedings, 24, 1217-1224.

15. Kholil, M., B. Hanum, \& I. Almahdy. (2020). Finishing Line Evaluation of Bracket Product Fwd Rr Spring Bt 1702 by Applying 8 Steps 7 Tools Method Toyota Production (Case Study: Pt Ba). Paper presented at the Journal of Physics: Conference Series. 
16. Singh, J. and H. Singh. (2009). Kaizen Philosophy: A Review of Literature. IUP journal of operations management, 8(2), 51-72.

17. Vo, B., E. Kongar, \& MFS. Barraza. (2019). Kaizen Event Approach: A Case Study in the Packaging Industry. International Journal of Productivity and Performance Management. https://doi.org/10.1108/IJPPM-072018-0282

18. Belhadi, A., F.E. Touriki, \& S. El Fezazi. (2018). Lean Implementation in Small and Medium-Sized Enterprises in Less Developed Countries: Some Empirical Evidences from North Africa. Journal of Small Business Management, 56, 132-153. https://doi.org/10.1108/JEDT-08-2017-0083

19. Kumar, S., A. Dhingra, \& B. Singh. (2018). Lean-Kaizen Implementation. Journal of Engineering, Design and Technology.

20. Bhanu, M.V. and P.B.S. Kumar. (2018). Global Study and Implementation of Karakuri.

21. Tangl, A. and I. Vajna. The Result of Lean Productivity Development Combined with Karakuri Kaizen Method. Paper presented at the ICoM 2018 8th International Conference On Management.

22. Murata, K. and H. Katayama. (2010). Development of Kaizen Case-Base for Effective Technology Transfer-a Case of Visual Management Technology. International Journal of Production Research, 48(16), 4901-4917.

23. Kurokawa, K. (2001). Kisho Kurokawa Architects and Associates: The Philosophy of Symbiosis from the Age of the Machine to the Age of Life. Edizioni Press.

24. Shamsudin, E., SAAZM Darus, P.S.A. Shah, P. Behrang, MRMH bin Raja, \& Z. Abidin. (2019). Implement Karakuri as a Material Handling in Production Sealer Line, in Green Technology and Engineering Seminar. 